\title{
Photosynthesis, respiration and whole plant carbon budget of the seagrass Thalassia testudinum
}

\author{
James W. Fourqurean, Joseph C. Zieman \\ Department of Environmental Sciences, The University of Virginia, Charlottesville, Virginia 22903, USA
}

\begin{abstract}
The photosynthesis versus irradiance (P/I) response of the seagrass Thalassia testudinum from Florida Bay, USA, was measured using the oxygen evolution of intact short shoots enclosed in sealed chambers, and found to have a light-saturated P/I behavior. All 4 of the commonly used mathematical formulations of the P/I curve were of equal utility in describing the data. When fit to the data using a least-squares fitting procedure, they produced nearly identical lines explaining $90 \%$ of the variance in the data. The estimates of the P/I model parameters $\alpha$ and $\mathrm{P}_{\max }$ produced by the 4 different formulations varied widely, however, so parameter values generated using one model cannot be used in other models. Green photosynthetic leaves account for only $15.0 \%$ of the total biomass of Florida Bay $T$. testudinum. The remaining $85 \%$ is apportioned into belowground short shoots, rhizomes and roots. Leaves had higher respiration rates $\left(7.4 \mu \mathrm{g} \mathrm{O}_{2} \mathrm{~g}^{-1} \mathrm{~min}^{-1}\right)$ than the belowground structures $(0.9$ to $4.6 \mu \mathrm{g}$ $\left.\mathrm{O}_{2} \mathrm{~g}^{-1} \mathrm{~min}^{-1}\right)$, and accounted for $42.6 \%$ of total plant respiration. The P/I curve and respiration data were used to build a daily carbon budget for Florida Bay T. testudinum. Estimated carbon fixation rates agreed closely with previously collected field ${ }^{14} \mathrm{C}$ uptake measurements. Under average summer light conditions, the budget was positive as deep as $4 \mathrm{~m}$, suggesting that plants can survive at this depth. $\mathrm{H}_{\text {sat }}$ was $0 \mathrm{~h}$ at depths greater than $3 \mathrm{~m}$, however.
\end{abstract}

\section{INTRODUCTION}

In the last $50 \mathrm{yr}$, there has been a precipitous decline in the areal extent of seagrass beds in many parts of the world. Often these declines have been linked to reduced water quality and increased turbidity, which decrease the amount of light available to benthic plants (Zieman 1975, Orth \& Moore 1983, Cambridge \& McCoomb 1984, Geisen et al. 1990, Larkum \& West 1990). Reduced light levels may restrict seagrasses to shallower areas, since the depth limits of some seagrasses are considered to be controlled by the penetration of light in the water column (Wetzel \& Penhale 1983, Dennison \& Alberte 1985, Dennison 1987). Vicente \& Rivera (1982) reported that the depth limit of Thalassia testudinum Banks ex König in Puerto Rico is closely correlated to the mean Secchi depth over the seagrass beds, illustrating the importance of light intensity to depth limits.

In order to predict the response of seagrasses to changes in environmental light regimes, the photosynthesis versus irradiance (P/I) response of seagrasses must be understood. Previous studies have shown that in general seagrasses show a light-limited phase of photosynthesis at low light intensities, where there is a linear increase in photosynthetic rate as light increases, while at higher light intensities there is a light-saturated response in which photosynthetic rate remains constant as light increases (see Drew 1979, Dennison 1987 for reviews). In this behavior, seagrasses are similar to phytoplankton and terrestrial $\mathrm{C}_{3}$ plants.

In addition to an understanding of the environmental variables which govern the P/I relationship, the mathematical formulation of the P/I curve must be understood if successful mechanistic models of seagrass growth as a function of light are to be produced. Most of the work done on the mathematical formulation of the relationship of photosynthesis to irradiance in aquatic and marine systems has been done with laboratory cultures or natural assemblages of phytoplankton. Several models (Table 1) have been proposed to describe the light-saturated response of photosynthesis to irradiance illustrated in Fig. 1. The 2 parameters common to all of these models are $\alpha$ and 
Table 1. Two-parameter gross photosynthesis $\left(\mathrm{P}_{\mathrm{g}}\right)$ versus irradiance (I) models. All models expressed in terms of $\alpha$ and $\mathrm{P}_{\max }$

\begin{tabular}{|ll|}
\hline \multicolumn{1}{|c|}{ Equation } & \multicolumn{1}{c|}{ Source } \\
\hline 1. $\mathrm{P}_{\mathrm{g}}=\alpha \mathrm{I} \quad\left(\right.$ if $\left.\mathrm{I} \leq \mathrm{P}_{\max } / \alpha\right)$ & Blackman (1905) \\
$\mathrm{P}_{\mathrm{g}}=\mathrm{P}_{\max }\left(\right.$ if $\left.\mathrm{I}>\mathrm{P}_{\max } / \alpha\right)$ & \\
2. $\mathrm{P}_{\mathrm{g}}=\mathrm{P}_{\max } \alpha \mathrm{I} /\left(\mathrm{P}_{\max }+\alpha \mathrm{I}\right)$ & $\begin{array}{l}\text { Burk \& Lineweaver } \\
\text { (1935) }\end{array}$ \\
3. $\mathrm{P}_{\mathrm{g}}=\mathrm{P}_{\max } \alpha \mathrm{I} /\left[\mathrm{P}_{\max }{ }^{2}+(\alpha \mathrm{I})^{2}\right]^{0.5}$ & Smith (1936) \\
4. $\mathrm{P}_{\mathrm{g}}=\alpha \operatorname{Iexp}\left(-\alpha \mathrm{I} / \mathrm{P}_{\max } \mathrm{e}\right)$ & Steele (1962) \\
5. $\mathrm{P}_{\mathrm{g}}=\mathrm{P}_{\max }\left[1-\exp \left(-\alpha \mathrm{I} / \mathrm{P}_{\max }\right)\right]$ & Webb et al. (1974) \\
6. $\mathrm{P}_{\mathrm{g}}=\mathrm{P}_{\max } \tanh \left(\alpha \mathrm{I} / \mathrm{P}_{\max }\right)$ & Jassby \& Platt (1976) \\
\hline
\end{tabular}

$\mathrm{P}_{\max }$. The slope of the function at $\mathrm{I}=0, \alpha$, is often referred to as the initial slope and is related to the maximum quantum yield of the photosynthetic apparatus (Rabinowitch \& Govindjee 1969, Jassby \& Platt 1976). $\mathrm{P}_{\max }$ is the plateau height of the curve, and is controlled by the processing time of the dark reactions of photosynthesis (Rabinowitch \& Govindjee 1969, Falkowski 1980). All of these models are based on mathematical intuition: they were chosen because they fit the empirical data, not because of any mechanistic or physiological relationship between photosynthesis and irradiance. Due to the intuitive nature of these models, all of them fit observed data reasonably well. The relative merits of these mathematically different models have been compared for phytoplankton (Jassby \& Platt 1976, Gallegos \& Platt 1981, Lederman \& Tett 1981) and for streams dominated by freshwater macrophytes (Cosby 1984). A similar comparison of photosynthesis versus irradiance models has not been made for seagrasses.

The carbon balance of seagrasses is more complex than that of phytoplankton, due to the increased structural complexity of seagrasses. A large portion of the biomass of seagrasses is allocated to non-photosynthetic tissue that must be supported by the photosynthesis of the leaves. The apportionment of plant resources into leaves and non-photosynthetic tissues can vary not only between species, as is evident by the different growth forms of seagrass species, but also within a species. For Thalassia testudinum, for example, leaves compose between 10 and $45 \%$ of the total biomass (Zieman 1982). This variation may be caused by environmental factors such as nutrient availability or sediment type (Burkholder et al. 1959, Kenworthy \& Fonseca 1977, Zieman 1982). The effect of this variation on the ability of seagrasses to maintain a net positive carbon balance has only recently been investigated (Zimmerman et al. 1989).

The objectives of this research were to describe the photosynthesis versus irradiance behavior and respira-

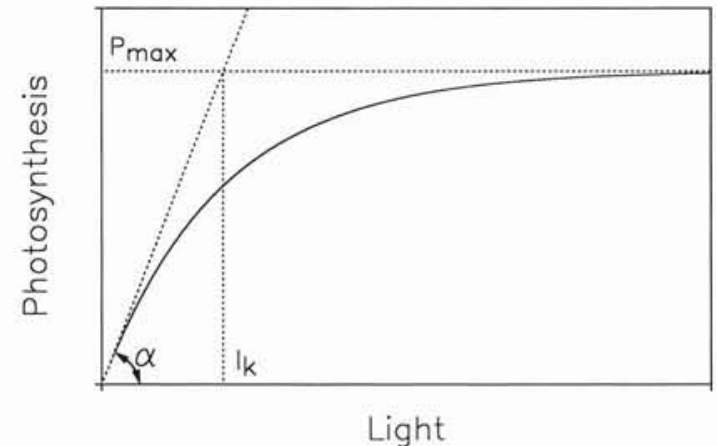

Fig. 1. Definition of the model parameters $\alpha$ and $\mathrm{P}_{\max }$ on a hypothetical photosynthesis versus irradiance (P/I) curve. $P_{\max }$ is the asymptotically approached maximum value for $\mathrm{P}$ at high irradiance levels, $\alpha$ is the slope of the curve at $\mathrm{I}=0$, and $\mathrm{I}_{\mathrm{k}}$ is the ratio of $\mathrm{P}_{\max } / \alpha$

tion of the dominant seagrass of south Florida and the Caribbean, Thalassia testudinum, and to investigate how these factors interact to control the carbon budget of this species. We generated photosynthesis versus irradiance data for entire short shoots by measurig oxygen evolution and uptake at various light intensities and tested the ability of 4 of the most common photosynthesis versus irradiance equations to describe this data. The apportionment of plant biomass into various plant tissues was measured in the field, and the respiration rates of different parts of the plants were determined. We then used this information to construct a simple photosynthesis and respiration carbon budget model for $T$. testudinum.

\section{METHODS}

Seagrass collection. All plants for these experiments were collected in Florida Bay, Florida, USA $\left(25^{\circ} \mathrm{N}\right.$, $\left.81^{\circ} \mathrm{W}\right)$ near Crane and Panhandle Keys, which are in the East Central community as described by Zieman et al. (1989). Specimens were collected from the bottom of tidal channels ( 1.5 to $2 \mathrm{~m}$ deep) and shipped to Charlottesville, Virginia, USA for experiments. Plants were collected as sods by SCUBA divers, and care was taken to include as much of the root and rhizome structure of the plants as possible. Sediment was washed from the sods by gentle agitation of the specimens in nylon mesh bags. Washed sods were then placed in plastic bags, sealed in styrofoam coolers, and air-freighted to Charlottesville. Total time between collection of the plants and their arrival in the lab was 24 to $48 \mathrm{~h}$. Plants were kept in 2401 temperature-controlled aquaria filled with synthetic seawater (Instant Ocean, $30 \mathrm{ppt}$ ) with the temperature set to approximate field conditions (25 to $30^{\circ} \mathrm{C}$ ). Illumination in these holding tanks was provided by $400 \mathrm{~W}$ mercury vapor lamps with a photo- 
period of $12 \mathrm{~h}$ light: $12 \mathrm{~h}$ dark. Light intensities reaching the plants were about $500 \mu \mathrm{E} \mathrm{m}^{-2} \mathrm{~s}^{-1}$. All plants were allowed to equilibrate in the holding tanks for $7 \mathrm{~d}$ before experimentation.

Photosynthesis measurements. Photosynthesis was measured as the change in dissolved oxygen concentrations in sealed 3.81 plexiglass cylinders, each with a magnetic stirrer, a Clark-type polarographic oxygen probe (YSI model 5740) and a $2 \pi$ submersible light sensor (Li-Cor model 192s, Fig. 2). Both the oxygen probes and light sensors were interfaced to an analogto-digital converter housed a microcomputer. The chambers were immersed in a 2401 temperature control bath. Experiments were conducted between 25 and $30^{\circ} \mathrm{C}$. A light bank consisting of 5 mercury vapor lamps $(400 \mathrm{~W}), 6$ incandescent flood lamps $(150 \mathrm{~W})$, and 2 sodium halide lamps (300 and $500 \mathrm{~W}$ ) supplied about

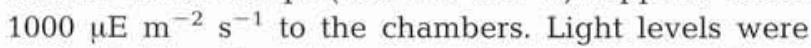
controlled by the placement of neutral gray filters, made of fiberglass window screening, between the light bank and the bath. Darkness was obtained by shutting out all of the room lights.

For each experimental run, plants appearing healthy were selected from the holding tanks. Epiphytes and dead tissues were gently removed, and intact short shoots were separated from roots and rhizomes. From 4 to 6 short shoots of Thalassia testudinum were used in each measurement. These shoots were rinsed in clean synthetic seawater and secured upright by spring clips inside the chambers. The chambers were filled with $\mathrm{N}_{2}$-sparged synthetic seawater, sealed, placed in the

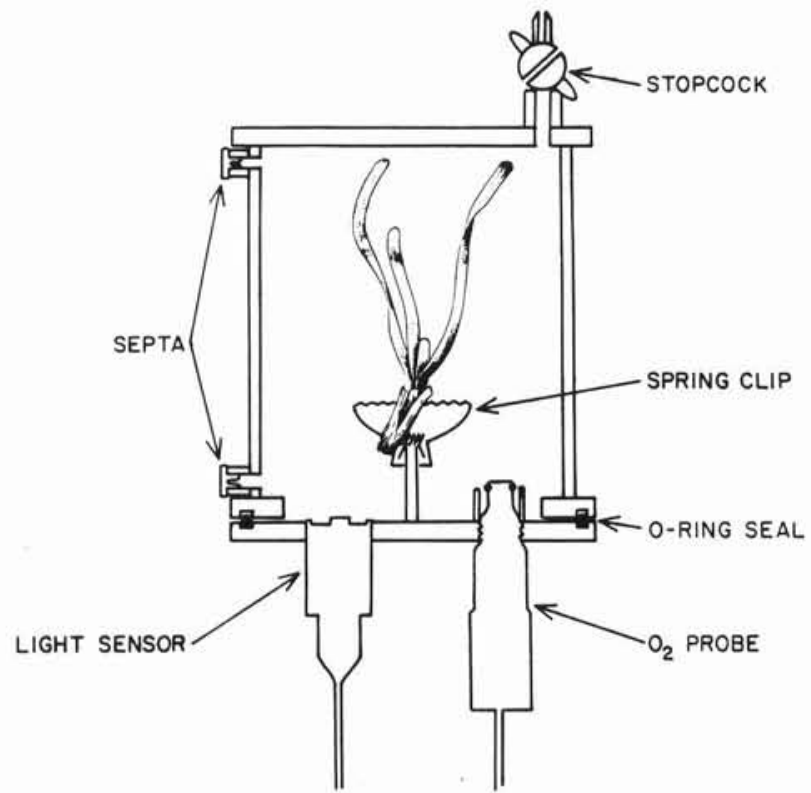

Fig. 2. Diagram of chambers used for photosynthesis measurements. The walls, top and bottom of the chamber were constructed of clear acrylic. Magnetically coupled stirring mechanism not shown for clarity temperature-controlled bath and allowed to equilibrate in the dark for $1 \mathrm{~h}$. After equilibration, any gas bubbles remaining in the chambers were removed. The plants were then subjected to 8 different light levels in a predetermined and randomized order. The order of the light levels was randomized in order to avoid biasing the data with possible light history effects. Initially, each light level lasted for $1 \mathrm{~h}$; this interval was subsequently shortened to $30 \mathrm{~min}$ due to the rapid stabilization ( 3 to $5 \mathrm{~min}$ ) of the rate of oxygen evolution after a change in light. After the completed run, the chambers were opened and the plant material was separated into photosynthetic and non-photosynthetic parts, and both portions were lyophilized and then weighed to determine biomass.

Photosynthetic rates were calculated from dissolved oxygen concentration changes in the chamber. Net chamber photosynthesis ( $\left.\mathrm{P}_{\text {chamber net (I) }}\right)$ was calculated for each light level of a run as the difference between the amount of oxygen in the chambers at the beginning and end of each light level. Chamber respiration rates $\left(R_{\text {chamber }}\right)$ were calculated as the change in oxygen in the chambers during the dark period of the run. Gross photosynthesis at irradiance I $\left(\mathrm{P}_{\mathrm{g}(\mathrm{I})}\right)$ was calculated for each light level in a run as the difference between the net chamber photosynthetic rate and the chamber respiration rate, and then normalized to the biomass of the leaf portion of then plants used in the run, $\mathrm{B}_{\text {leaf }}$ :

$$
\mathrm{P}_{\mathrm{g}(\mathrm{I})}=\left[\mathrm{P}_{\text {chamber net (I) }}-\mathrm{R}_{\text {chamber }}\right] / \mathrm{B}_{\text {leaf }}
$$

Gross photosynthetic rates were expressed in units of $\mu \mathrm{g} \mathrm{O}_{2}$ (g dry wt leaf) ${ }^{-1} \mathrm{~min}^{-1}$.

Photosynthesis vs irradiance model comparison. Gross photosynthesis was plotted against irradiance and 4 commonly used photosynthetic models were fit to the data using a least-squares non-linear curve fitting procedure. Out of the possible models in the literature available for comparison, we chose nos. 2, 3, 5 and 6 from Table 1 for this exercise based on Cosby's (1984) analysis of model adequacy for macrophyte-dominated streams. Estimates of the model parameters $\alpha$ and $\mathrm{P}_{\max }$ were made for each model, and the constant $I_{k}$ was calculated for each model; $I_{k}$ is defined as the ratio of the 2 model parameters $\alpha$ and $\mathrm{P}_{\max }$ :

$$
\mathrm{I}_{\mathrm{k}}=\mathrm{P}_{\max } / \alpha .
$$

These 4 models were then compared for their ability to describe the variation of the data $\left(\mathrm{R}^{2}\right)$. A graphical examination of the residuals was also performed to determine if there were any systematic differences between the models at various light intensities.

Respiration measurements. Seagrass samples for respiration measurements were collected from the same field sites as for the P/I experiments, but the measurements were made immediately after collection 
at a shore facility. Plants were separated into green leaf tissue, upright non-photosynthetic portions of the short shoots, rhizomes and roots, and thoroughly washed in flowing seawater to remove sediment and epiphytes. Washed plant tissues were placed in $300 \mathrm{ml}$ BOD (biological oxygen demand) bottles filled with seawater and equipped with magnetic stirrers. These bottles were incubated in the dark in a constant temperature bath $\left(26\right.$ to $\left.28^{\circ} \mathrm{C}\right)$, and the oxygen concentrations in each bottle were measured before and after a $3 \mathrm{~h}$ incubation period. In control incubations of seawater only, there was negligible uptake of oxygen in the $3 \mathrm{~h}$ period. The tissues from each bottle were removed and lyophilized. Respiration rates were normalized to the dry weight of the plant tissues in each bottle, and expressed as $\mu \mathrm{g} \mathrm{O}_{2} \mathrm{~g}^{-1}$ dry wt $\min ^{-1}$. An ANOVA with a Student-Neuman-Keuls range test was used to test for differences between respiration rates of the different tissues $\left(\mathrm{R}_{\text {tissue; }}\right.$ tissue $=$ leaf, shoot, rhizome or root).

Biomass apportionment. Forty Thalassia testudinum samples were collected using core tubes (15 or $19 \mathrm{~cm}$ diameter) from locations throughout Florida Bay to estimate the relative apportionment of plant biomass into 4 tissue types: leaves, non-photosynthetic portions of the short shoots, rhizomes and roots. At each sampling location, duplicate cores were collected. Cores were washed thoroughly on a $5 \mathrm{~mm}$ mesh screen to remove sediments, epiphytes and shell material. All of the living plant biomass was separated into the 4 tissue types. Leaves and shoots were separated by color: any green portion was included in leaves and white parts were included in the short shoots. Individual samples were lyophilized, weighed and the relative contribution of each portion to the total biomass was calculated.

Photosynthesis and respiration budget. A simple type of budget including photosynthesis and respiration may be made at the level of the leaves. Compensation irradiance is the light level at which gross photosynthesis and respiration are equal. For each model, compensation irradiance for leaf tissue $\left(I_{c}\right.$ leaf $)$ was estimated by setting $\mathrm{P}_{\mathrm{g}}$ equal in magnitude to the leaf respiration rate and solving for $\mathrm{I}=\mathrm{I}_{\mathrm{c}}$ leaf.

Photosynthesis and respiration budgets for whole plants must take into account the respiratory demand of the non-photosynthetic parts of the plants. Simple balances between oxygen evolved during photosynthesis and oxygen consumed during respiration are not adequate to describe the carbon budget of plants because there is not a 1:1 correspondence of moles of carbon and moles of oxygen in respiration and photosynthesis. Photosynthetic quotient $\left(\mathrm{PQ}=\right.$ moles $\mathrm{O}_{2} /$ moles $\mathrm{C}$ during photosynthesis) has been estimated as 1.2 for submerged aquatics by Westlake (1963) and 1.27 for Potomageton by Kemp et al. (1986). In this exercise, we converted oxygen evolution to carbon fixation assuming $P Q=1.2$. Due to the lack of data available on the respiratory quotients $(\mathrm{RQ}=$ moles $\mathrm{C}$ oxidized/moles $\mathrm{O}_{2}$ consumed) of seagrasses, we converted oxygen consumption to carbon oxidation during respiration assuming $R Q=1$. This value is typical of leaves and seeds of many species of terrestrial plants that use starches and sugars as respiratory substrates (Salisbury \& Ross 1978).

Daily respiration was estimated by assuming that respiration rates of all tissues were constant throughout the day. Daily demand was calculated by multiplying the rates of respiration for each tissue by the fraction of the plant composed of that tissue, summing over all tissues, and integrating over $24 \mathrm{~h}$. These rates were then expressed as a function of the weight of leaf tissue to make comparisons with photosynthesis more facile.

We chose one model from the 4 tested in the above section to simulate the daily photosynthesis of Thalassia testudinum. In order to estimate daily gross photosynthesis, we collected incident irradiance data hourly for $2 \mathrm{wk}$ in early August 1988, at a field station on Florida Bay, using a $2 \pi$ quantum sensor. The hourly readings were averaged over the $2 \mathrm{wk}$ period to produce an average summer day. Using submersible $2 \pi$ quantum sensors at different depths (z), water column light extinction coefficients $\left(k\right.$, where $\left.I_{z}=I_{0} e^{-k z}\right)$ were measured at 13 sites across the bay to estimate average transmittance of light to underwater plants. The daily time series of light at depth was used to estimate daily gross photosynthesis as a function of the mass of leaf tissue. The length of the periods of $\mathrm{H}_{\text {sat }}$ and $\mathrm{H}_{\text {comp }}$ at each depth were also calculated following the techniques of Dennison \& Alberte (1982). $\mathrm{H}_{\text {sat }}$ is defined as the length of time that the incident irradiance (I) is greater than $\mathrm{I}_{\mathrm{k}}$, and $\mathrm{H}_{\text {comp }}$ is defined as the length of time that $I$ is greater than $I_{c}$ leaf.

\section{RESULTS}

\section{Photosynthesis measurements}

In these experiments, Thalassia testudinum exhibited typical photosynthesis versus irradiance behavior, with rapid increases in photosynthesis with increasing light at low irradiance, then an asymptotic approach to a maximum rate at higher light intensities (Fig. 3). There was no apparent photoinhibition at high light intensities. At high intensities, there was more variation in the measured photosynthetic rate.

\section{Photosynthesis versus irradiance model comparison}

The 4 models produced almost identical lines when fit to the data (Fig. 3); all described $90 \%$ of the varia- 


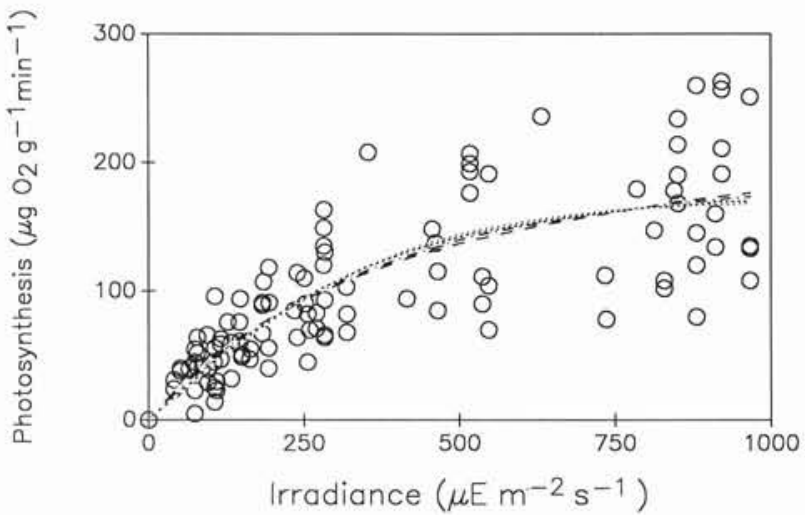

Fig. 3, Thalassia testudinum. Data from the chamber P/I experiments using intact shoots, and results of fitting common $\mathrm{P} / \mathrm{I}$ models to the data using a least-squares technique. Note the similarity of the 4 lines

tion in the data (Table 2). The obvious similarity of the lines produced by the 4 models was also evident in plots of the residuals (Fig. 4). There were no differences in the pattern or magnitude of the residuals resulting from the 4 different formulations of the P/I relationship. These results suggested that all 4 of the P/I equations tested were of equal utility in describing the P/I response of Thalassia testudinum measured in these experiments.

The models did produce different estimations of the values of the model parameters, however (Table 2). Values of $\alpha$ ranged from 0.420 to 0.585 , and $P_{\max }$ ranged from 171 to $256 \mu \mathrm{g} \mathrm{O}_{2}$ (g leaf) ${ }^{-1} \mathrm{~min}^{-1}$. There was also variation in the estimate of $I_{k}$ among the models tested, from 357 to $438 \mu \mathrm{E} \mathrm{m}^{-2} \mathrm{~s}^{-1}$.

\section{Respiration and biomass apportionment measure- ments}

There were significant differences in the respiration rates of different plant parts (Table 3). Green leaves had the highest rate, followed by roots, and then the non-photosynthetic portions of the short shoots and rhizomes, which were not significantly different.

For the 40 cores taken across Florida Bay, the average Thalassia testudinum biomass was $900.5 \mathrm{~g}$ dry wt $\mathrm{m}^{-2}$, with a range of 194.8 to $2254.2 \mathrm{~g}$ dry wt $\mathrm{m}^{-2}$ (Table 4). Leaf biomass, often called standing crop in seagrass literature, averaged $142.7 \mathrm{~g}_{\text {dry wt }}{ }^{-2}$, with a range of 25.2 to $470.4 \mathrm{~g}$ dry $\mathrm{wt} \mathrm{m}^{-2}$. The relative contribution of each plant component to the total biomass is shown in the top half of Fig. 5 and listed in Table 4 . Leaves made up an average of $15.0 \pm 1.0 \%$ of the total biomass of each core, short shoots $40.4 \pm$ $1.2 \%$, rhizomes $34.8 \pm 1.7 \%$ and roots $9.9 \pm 0.6 \%$. There was a large range in the relative importance of
Table 2. Comparison of model parameters obtained by fitting the different photosynthesis models to the data. Model numbers refer to equations from Table 1

\begin{tabular}{|ccccc|}
\hline Model & $\mathrm{R}^{2}$ & $\alpha^{\mathrm{a}}$ & $\begin{array}{c}\mathrm{P}_{\max } \\
\left(\mu \mathrm{g} \mathrm{O}_{2} \mathrm{~g}^{-1} \min ^{-1}\right)\end{array}$ & $\begin{array}{c}\mathrm{I}_{\mathrm{k}} \\
\left(\mu \mathrm{E} \mathrm{m}^{-2} \mathrm{~s}^{-1}\right)\end{array}$ \\
\hline 2 & 0.90 & 0.585 & 256 & 438 \\
3 & 0.90 & 0.437 & 186 & 407 \\
5 & 0.90 & 0.518 & 185 & 357 \\
6 & 0.90 & 0.420 & 171 & 426 \\
\multicolumn{4}{l}{ a Units for $\alpha\left(\mu \mathrm{g} \mathrm{O}_{2} \mathrm{~g}^{-1} \min ^{-1}\right)\left(\mu \mathrm{E} \mathrm{m}^{-2} \mathrm{~s}^{-1}\right)^{-1}$} \\
\hline
\end{tabular}

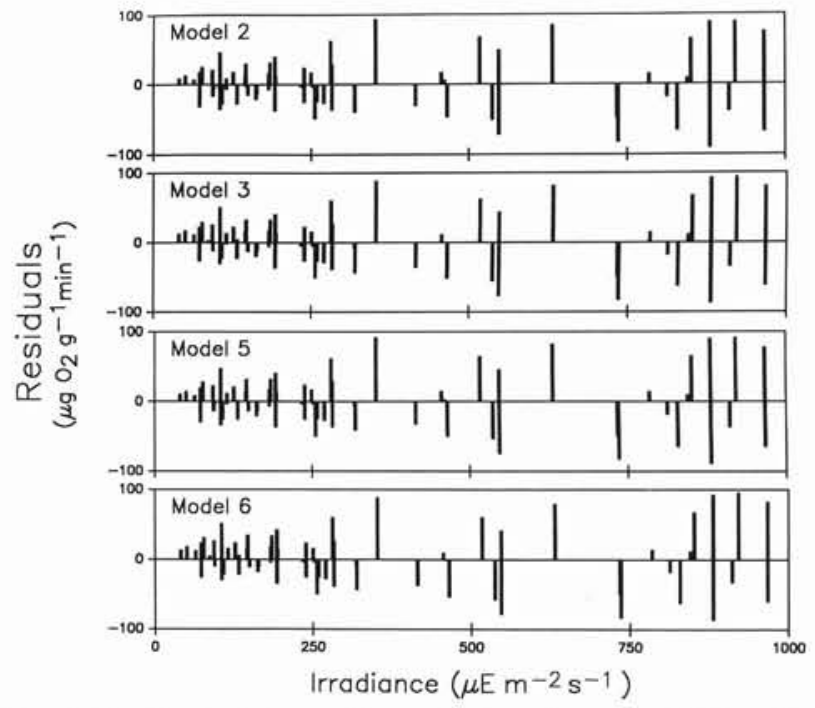

Fig. 4. Residuals of the model predictions from Fig. 3. Note the similarity of the residuals. Model numbers refer to the equations in Table 1

each tissue. Leaves accounted for as little as $5.9 \%$ and as much as $29.9 \%$ of the total biomass. There were similar variations in the other tissues. The bottom half of Fig. 5 shows the relative importance of the plant components to total plant respiration. Note that although short shoots and rhizomes comprised $75 \%$ of

Table 3. Thalassia testudinum. Results of respiration measurements for different plant tissues. The short shoot component included only the non-photosynthetic portions of the short shoot. Groups marked with an asterisk were not significantly different at $\mathrm{p}=0.05$

\begin{tabular}{|lccc|}
\hline Plant part & \multicolumn{2}{c|}{$\begin{array}{c}\text { Respiration rate } \\
\left(\mu \mathrm{g} \mathrm{O}_{2}\left(\mathrm{~g} \text { dry } \mathrm{wt}^{-1} \mathrm{~min}^{-1}\right)\right. \\
\mathrm{Mean}\end{array}$} & $\mathrm{SD}$ \\
\hline Leaves & 7.4 & 1.5 & 17 \\
Short shoots $^{*}$ & 1.8 & 0.6 & 15 \\
Rhizomes & 0.9 & 0.3 & 17 \\
Roots & 4.6 & 2.4 & 18 \\
\hline
\end{tabular}


Table 4. Thalassia testudinum. Apportionment of biomass into leaves, non-photosynthetic portions of the short shoots, rhizomes and roots for plants from 40 cores taken across Florida Bay. SE = standard error

\begin{tabular}{|c|c|c|c|c|c|}
\hline & Leaf & Short shoot & $\begin{array}{c}\text { Plant tissue } \\
\text { Rhizome }\end{array}$ & Root & Total \\
\hline Mean & 142.7 & 381.5 & 278.1 & 98.2 & 900.5 \\
\hline SE & 18.6 & 46.1 & 25.0 & 14.2 & 92.3 \\
\hline Minimum & 25.2 & 78.6 & 80.8 & 10.0 & 194.8 \\
\hline Mean & 15.0 & 40.4 & 34.8 & 9.9 & 100.0 \\
\hline $\mathrm{SE}$ & 1.0 & 1.2 & 1.7 & 0.6 & \\
\hline Minimum & 5.6 & 28.7 & 12.8 & 5.1 & \\
\hline Maximum & 29.9 & 67.5 & 60.0 & 19.8 & \\
\hline
\end{tabular}

the biomass, they accounted for only $40 \%$ of the total respiratory demand of the plant.

\section{Photosynthesis and respiration budget}

Only relatively low light levels were required for leaf tissue to produce oxygen during photosynthesis at a greater rate than consume it during respiration. All 4 models predicted similar values of $\mathrm{I}_{\mathrm{c}}$ leafi estimates ranged between 15.1 and $15.7 \mu \mathrm{E} \mathrm{m}^{-2} \mathrm{~s}^{-1}$.

\section{Biomass}

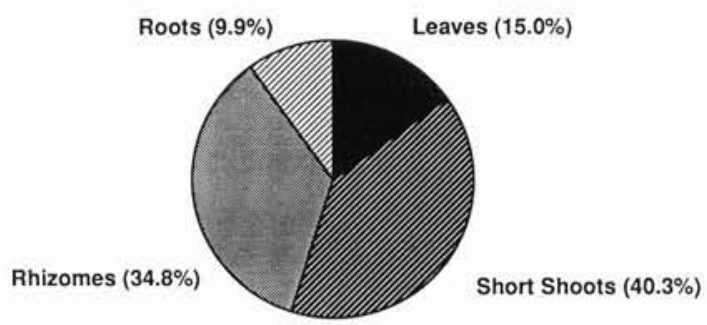

\section{Respiration}

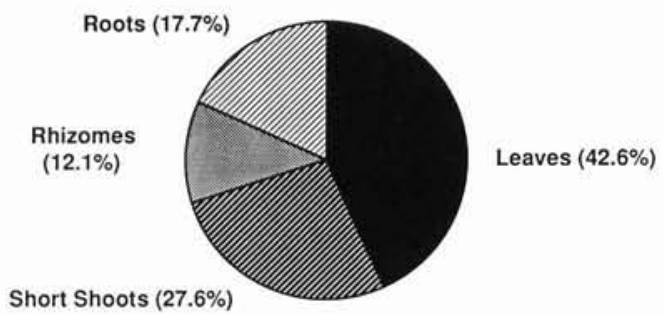

Fig. 5. Thalassia testudinum. Relative importance of each tissue type to the total biomass of $T$. testudinum from Florida Bay (top), and relative contribution of each tissue type to the respiratory demand of the whole plant (bottom). The short shoot component included only the non-photosynthetic portions of the short shoots
Because of the similarity in the ability of the 4 tested equations to describe the shape of the P/I curve, there was no clear 'best' form of the relationship between photosynthesis and irradiance. In the absence of differences in model performance, we chose to use the mathematically simplest form (model 2) for carbon budget calculations.

The extinction coefficient (k) of Florida Bay water averaged $0.51(\mathrm{SD}=0.19, \mathrm{n}=13)$. Fig. 6 shows measured average daily surface irradiance for early August 1988 , and estimates of irradiance at depth for depths of 1 to $5 \mathrm{~m}$ assuming $\mathrm{k}=0.51$. The estimated diurnal curves of gross photosynthesis at these depths are shown in Fig. 7, and the total daily gross carbon fixation from these curves is shown in Table 5 .

One gram of Florida Bay Thalassia testudinum tissue, apportioned into components as shown in the top half

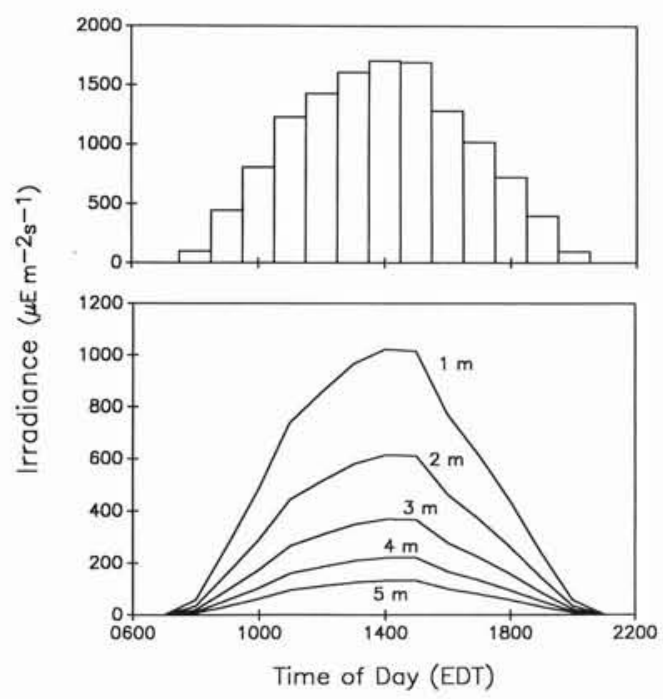

Fig. 6. Surface irradiance versus time of day for a typical summer day' (see text) in the Florida Keys. Top: measured surface irradiance; bottom: estimated irradiance at depths of 1 to $5 \mathrm{~m}$ 


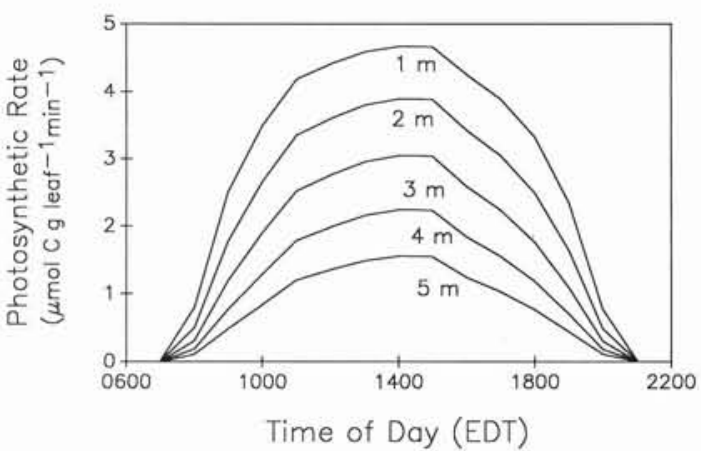

Fig. 7. Thalassia testudinum. Estimated gross carbon uptake rates at depths of 1 to $5 \mathrm{~m}$ in Florida Bay, generated with the light curves in Fig. $6, \mathrm{k}=0.51$ and photosynthesis model 2 assuming $\mathrm{PQ}=1.2$

of Fig. 5, requires $0.081 \mu \mathrm{mol} \mathrm{C} \min ^{-1}\left(2.6 \mu \mathrm{g} \mathrm{O}_{2} \min ^{-1}\right)$, or $117 \mu \mathrm{mol} \mathrm{C} \mathrm{d}^{-1}\left(3744 \mu \mathrm{g} \mathrm{O}_{2} \mathrm{~d}^{-1}\right)$ to satisfy its respiratory requirements. Since $1 \mathrm{~g}$ of leaf tissue supports $6.67 \mathrm{~g}$ of total biomass, the respiratory requirement that must be satisfied by $1 \mathrm{~g}$ of leaf tissue is $780 \mu \mathrm{mol} \mathrm{C} \mathrm{d} \mathrm{d}^{-1}$ $\left(25000 \mu \mathrm{g} \mathrm{O}_{2} \mathrm{~d}^{-1}\right)$. In order to estimate net daily carbon incorporation, this value was subtracted from the total daily carbon fixation at each depth (Table 5). Estimated net photosynthesis was positive for depths of 1 to $4 \mathrm{~m}$, but negative at $5 \mathrm{~m}$.

The lengths of the time periods $\mathrm{H}_{\text {sat }}$ and $\mathrm{H}_{\text {comp }}$ decreased as light was attenuated with depth (Table 5). $\mathrm{H}_{\text {sat }}$ had a maximum length of $10.3 \mathrm{~h}$ at a depth of $1 \mathrm{~m}$, but quickly decreased to 0 at depths of $3 \mathrm{~m}$ and greater. $\mathrm{H}_{\text {comp }}$ showed a much smaller decrease with depth than $\mathrm{H}_{\text {sat }}$, from $13.5 \mathrm{~h}$ at $1 \mathrm{~m}$ to $11.5 \mathrm{~h}$ at $5 \mathrm{~m}$.

\section{DISCUSSION}

Methods of measuring photosynthesis of seagrasses based on gas exchange techniques have been criticized due to the effects of storage of respiratory gases within the seagrasses and the diffusion of these gases between the plant and the surrounding water (Zieman \& Wetzel 1980). For freshwater macrophytes, however, many authors have concluded that lacunar storage was a minor source of error in determining productivity using oxygen techniques (Westlake 1978, Kelly et al. 1981, Kemp et al. 1986). Similarly, Drew (1978) and Wahbeh (1983) concluded that errors in photosynthesis measurements using oxygen techniques were also small for some seagrasses. In the well-stirred system used here, linear rates of oxygen evolution achieved within 3 to $5 \mathrm{~min}$ of irradiance change indicate that the effect of lacunar storage on measurements of oxygen evolution were small in this study.

The large variation in photosynthesis at a particular light level measured in this study (Fig. 3) was probably
Table 5. Estimated daily gross and net carbon fixation from the carbon budget calculation and estimates of the lengths of the time periods $\mathrm{H}_{\text {sat }}$ and $\mathrm{H}_{\text {comp }}$

\begin{tabular}{|ccccc|}
\hline $\begin{array}{c}\text { Depth } \\
(\mathrm{m})\end{array}$ & $\begin{array}{c}\text { Estimated photosynthesis } \\
\text { Daily gross } \\
\left(\mu \mathrm{mol} \mathrm{C}(\mathrm{g} \text { leaf })^{-1} \mathrm{~d}^{-1}\right)\end{array}$ & $\begin{array}{c}\mathrm{H}_{\text {sat }} \\
(\mathrm{h})\end{array}$ & $\begin{array}{c}\mathrm{H}_{\text {comp }} \\
(\mathrm{h})\end{array}$ \\
\hline & & & \\
\hline 1 & 2638.8 & 1858.8 & 10.38 & 13.5 \\
2 & 2047.8 & 1267.8 & 8.8 & 13.2 \\
3 & 1542.6 & 762.6 & 0 & 12.6 \\
4 & 1086.0 & 306.0 & 0 & 11.9 \\
5 & 729.6 & -50.4 & 0 & 11.5 \\
\hline
\end{tabular}

a consequence of many interacting factors, including the age of the leaves, the orientation of the leaves with respect to the light field and the immediate light history of the leaves. Also, the physiological health of the plants may have been influenced by harvesting, shipment and holding prior to the experimental runs. At higher light levels in particular, other factors, such as local nutrient availability, may be limiting photosynthesis. Mazzela \& Alberte (1986) have shown a large variation in photosynthetic rate in Zostera marina leaf sections of different ages. The average turnover rate of leaves for Florida Bay Thalassia testudinum is around $2 \% \mathrm{~d}^{-1}$ (Zieman et al. 1989), so the age of leaf tissue on any particular shoot used in these experiments varied between 0 and $50 \mathrm{~d}$.

Many other studies (Dennison \& Alberte 1982, 1985, Mazzela \& Alberte 1986, Zimmerman et al. 1989, etc.) of seagrass photosynthesis have used small sections of leaves held perpendicular to the incident irradiance. $\mathrm{P} / \mathrm{I}$ curves from these types of experiments have then been used to predict seagrass photosynthesis in the field, even though field measurements of light tend to be made of downwelling light while seagrass leaves in the field tend to be oriented nearly vertically. A more natural orientation of leaves to the light field was used in this study. Currents generated by the internal stirring of the experimental chambers caused a waving of the short shoots inside the chambers, thereby constantly changing the angle of the leaves to the incident light, much as occurs in nature. The angle of the leaves to incident light has been shown to have a major impact on photosynthesis of terrestrial plants (Campbell 1977), but this factor has been ignored to date in seagrass photosynthesis work. The spread of points in Fig. 3 probably is an accurate reflection of the variation of photosynthetic rate within a seagrass bed in the field, where many potentially limiting factors exist.

The nearly identical lines that resulted from the fitting of the $4 \mathrm{P} / \mathrm{I}$ models to the data suggest that the models were equally useful in describing the general shape of the P/I response. Any one of these models 
would be sufficient for the budget calculations made in this paper; they all described $90 \%$ of the variation in this data set generated over a wide range of irradiance values. The hyperbolic equation (model 2) was chosen for the carbon budget calculations based solely on the simplicity of the mathematics. Some attempt has been made to distinguish between the P/I models based on assumptions about the biology of photosynthesis. Chalker (1980) started with the assumptions that $\alpha=$ $\mathrm{P}_{\max } / \mathrm{I}_{\mathrm{k}}$ and $\mathrm{dP} / \mathrm{dI}=\mathrm{f}(\mathrm{P})$, and showed that model 5 results from the linear approximation of the power series expansion of $f(P)$. Similarly, he showed that model 6 is equivalent to the quadratic approximation of the same expansion. These results do not show that either model 5 or model 6 is a mechanistic model, but only that these 2 models are informed representations of the relationship instead of purely empirical relationships. The data presented here suggest that they are no better predictors than the purely empirical relationships, however.

Even though the 4 models tested were equal in their ability to describe the P/I data from these experiments, the estimates of the model parameters $\alpha$ and $\mathrm{P}_{\max }$ made with each model varied (Table 2). The coefficients of variation for the parameters estimates were $13.5 \%$ for $\alpha$ and $16.6 \%$ for $\mathrm{P}_{\max }$. Different estimates of the parameters result from the fact that the models were formulated based on mathematical intuition, and therefore these parameters should at best be considered rough estimates of biological phenomena. Parameter estimates made using one model cannot be directly compared to those made with another model. The differences in the models can be seen if all 4 models are plotted using the same value of the parameters (Fig. 8). For this exercise, we used the mean of the 4 determinations of the parameter values in Table $2\left(\alpha=0.490, \mathrm{P}_{\max }=\right.$ $199.5 \mu \mathrm{g} \mathrm{O}_{2} \mathrm{~g}^{-1} \mathrm{~min}^{-1}$ ). Note that predicted photo-

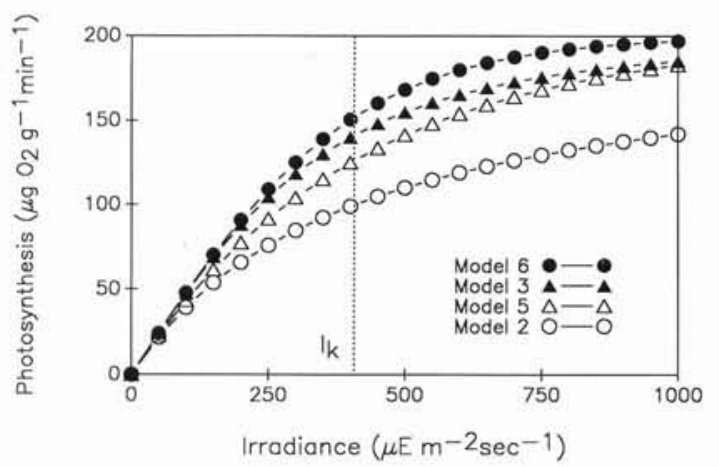

Fig. 8. Plots of 4 common P/I models using identical values of the model parameters $\alpha$ and $\mathrm{P}_{\max }$ to demonstrate the differences between the models. We used the means of the parameter values from the 4 fits given in Table 2. Model numbers refer to equations from Table 1 synthetic rates for model 2 are only 60 to $75 \%$ of the rates for model 6 .

Belowground structures, which account for $85 \%$ of the biomass of the Thalassia testudinum collected for this study (Fig. 5), have been largely neglected in investigations of seagrass photosynthesis and production. This study indicated that leaves accounted for less than half ( $42 \%$; Fig. 5) of the total plant respiration. The short shoots, rhizomes and roots of $T$. testudinum are therefore very important in the carbon budget of this species. This is not only true for $T$. testudinum; in a recent paper, Zimmerman et al. (1989) conclude that the shoot: root ratio is also very important in the carbon budget of Zostera marina. Since the proportion of the biomass of $T$. testudinum allocated to the different plant structures varies so widely (Table 4 and Zieman 1982), knowledge of the apportionment of biomass, and the factors governing the apportionment, are critical to modelling the carbon budget of the seagrasses of any location.

In our carbon budget calculations, we assumed constant carbon consumption rates throughout the day. We also measured oxygen uptake during respiration of belowground structures in highly artificial circumstances: we placed plant parts that normally exist in anoxic sediments in aerated water. These methods probably produced good first estimates of the actual carbon consumption rate, however. Smith et al. (1988) found that rates of aerobic carbon consumption for the roots of Zostera marina are approximately equal to anaerobic carbon consumption.

Carbon budget calculations required the conversion of oxygen evolution rates measured in the laboratory to estimates of carbon fixation in the field. Even though this conversion required some assumptions, predictions of carbon fixation agreed remarkably well with measured carbon fixation rates from Florida Bay. In a previous study conducted in water depths from 1 to $2.5 \mathrm{~m}$, ${ }^{14} \mathrm{C}$ estimates of carbon uptake of Thalassia testudinum had a mean of $2.8 \mu \mathrm{mol} \mathrm{C}$ (g leaf) ${ }^{-1} \mathrm{~min}^{-1}$, with a range of 2.1 to $4.1 \mu \mathrm{mol} \mathrm{C}$ (g leaf) ${ }^{-1} \min ^{-1}$ (Zieman et al. 1989).Our predictions for peak carbon fixation in this study were 3.2 to $4.5 \mu \mathrm{mol} \mathrm{C}$ (g leaf) ${ }^{-1} \mathrm{~min}^{-1}$ over the same depth range (Fig. 7).

$\mathrm{I}_{\mathrm{c} \text { leaf }}$ estimates generated in this study (15.1 to 15.7 $\mu \mathrm{E} \mathrm{m}^{-2} \mathrm{~s}^{-1}$ ) for Thalassia testudinum were within the range of published values reported for other seagrasses (9 to $26 \mu \mathrm{E} \mathrm{m} \mathrm{m}^{-2} \mathrm{~s}^{-1}$; Dennison 1987), but were lower than the 24 to $45 \mu \mathrm{E} \mathrm{m}^{-2} \mathrm{~s}^{-1}$ reported for $T$. testudinum from west central Florida (Dawes \& Tomasko 1988). Drew (1979) found that compensation irradiances for excised leaf tissue of 6 other seagrasses were ca $1 \%$ of normal surface irradiance. Similarly, our values were roughly $1 \%$ of the average maximum surface irradiance measured during August 1988 (Fig. 6). The 
value of $I_{c}$ leaf, however, is not very useful for making ecological evaluations of the carbon budget of whole plants because of the large respiratory requirement of the short shoots, rhizomes and roots of seagrasses.

For a plant to survive over the long term, carbon fixation of the leaves must be greater than the carbon loss due to respiration of the entire plant. For the surface irradiance curve shown in Fig. 6 and the prevailing environmental conditions in Florida Bay, Thalassia testudinum plants at depths of 1 to $4 \mathrm{~m}$ had a net positive carbon balance, but at $5 \mathrm{~m}$, the carbon balance was negative (Table 5). The length of time a plant can survive with a net loss of carbon has not yet been investigated, but a continued net loss of carbon would eventually lead to the inability to survive.

This carbon budget was constructed using light data from a few weeks in the summer, and is therefore an incomplete picture. Seasonality and extremes of light availability, either due to changing sun angle, weather patterns or water clarity, must be considered when using this type of budget approach to predict the ability of seagrasses to survive in an area. Temperature may also play an important role in the carbon budget of seagrasses, since the rates of change of photosynthesis and respiration with temperature are different (Marsh et al. 1986, Fourqurean 1987), but thermal acclimation of seagrasses may ameliorate temperature effects (Zimmerman et al. 1989).

The lengths of the periods $\mathrm{H}_{\text {sat }}$ and $\mathrm{H}_{\text {comp }}$ have been used to predict successfully photosynthesis, growth and depth limits of Zostera marina (Dennison \& Alberte 1982, 1985). Denison (1987) estimated daily photosynthesis for $Z$. marina by multiplying $\mathrm{H}_{\text {sat }}$ by $\mathrm{P}_{\max }$ and found a strong relationship between leaf growth and this estimate. This technique provides a good first approximation of daily photosynthesis, but there may be situations where it is inappropriate. Clearly photosynthesis occurs when light levels are below $\mathrm{I}_{\mathrm{k}}$ : at depths of 3 to $5 \mathrm{~m}, \mathrm{H}_{\text {sat }}$ for Thalassia testudinum in Florida Bay was $0 \mathrm{~h}$, but we estimated quite substantial carbon fixation rates at those depths (Table 5). The $\mathrm{H}_{\text {sat }}$ technique also will lead to overestimation of photosynthesis when irradiances are close to but greater than $\mathrm{I}_{\mathrm{k}}$. The magnitude of this error will depend on the form of the P/I relationship employed, since as a result of the mathematics of the P/I equations in Table $1, P$ at $I_{k}$ is $0.50 \times \mathrm{P}_{\max }$ for model 2 and $0.70 \times \mathrm{P}_{\max }$ for model 6 (Fig. 8).

In summary, we found that Thalassia testudinum exhibits a light-saturated photosynthesis versus irradiance behavior, and that all 4 of the commonly used models of the P/I relationship that we tested were of equal value in describing the data. Differences in the forms of the equations make it imperative that model parameters derived with one model not be used with other models. Belowground structures of this species accounted for a substantial fraction of the respiratory demand for carbon, and were therefore important in the whole plant carbon budget. We estimated daily carbon fixation rates from oxygen evolution experiments, and these estimates were close to measurements made in the field. A daily carbon budget indicated that $T$. testudinum could survive as deep as $4 \mathrm{~m}$ in Florida Bay, even though $\mathrm{H}_{\text {sat }}$ was $0 \mathrm{~h}$.

Acknowledgements. We thank K. J. Halama, M. McManus, G. V. N. Powell and A. H. Powell for assisting in the field collections for this paper. H. Cruden and E. B. Rastetter provided invaluable assistance in the design and construction of the photosynthesis apparatus. R. M. Chambers, J. W. Harvey, W. J. Kenworthy and one anonymous reader reviewed earlier versions of this manuscript and made many suggestions that greatly improved the finished paper. Laboratory space in Florida was graciously provided by the Ornithological Research Unit of the National Audubon Society. Partial funding for this work was provided by a Fred Holmsley Moore research grant and a graduate research award from the Department of Environmental Sciences at the University of Virginia.

\section{LITERATURE CITED}

Blackman, F. F. (1905). Optima and limiting factors. Ann. Bot. 19: 281-295

Burk, D., Lineweaver, H. (1935). The kinetic mechanism of photosynthesis. Cold Spring Harb. Symp. quant. Biol. 3: 165-183

Burkholder, P. R., Burkholder, L. M., Rivero, J.A. (1959). Some chemical constituents of turtle grass, Thalassia testudinum. Bull. Torrey Bot. Club 86 (2): 88-93

Cambridge, M. L., McCoomb, A. J. (1984). The loss of seagrasses in Cockburn Sound, Western Australia. I. The time course and magnitude of seagrass decline in relation to industrial development. Aquat. Bot. 20: 229-243

Campbell, G. S. (1977). An introduction of environmental biophysics. Springer-Verlag, New York

Chalker, B. E. (1980). Modelling light saturation curves for photosynthesis: an exponential function. J. theor. Biol. 84: 205-215

Cosby, B. J. (1984). Dissolved oxygen dynamics of a stream: model discrimination and estimation of parameter variability using an extended Kalman filter. Wat. Sci. Tech. 16: 561-569

Dawes, C. J., Tomasko, D. A. (1988). Depth distribution of Thalassia testudinum in two meadows on the west coast of Florida; a difference in effect of light availability. P.S.Z.N.I: Mar. Ecol. 9 (2): 123-130

Dennison, W. C. (1987). Effects of light on seagrass photosynthesis, growth and depth distribution. Aquat. Bot. 27: $15-26$

Dennison, W. C., Alberte, R. S. (1982). Photosynthetic responses of Zostera marina L. (eelgrass) to in situ manipulations of light intensity. Oecologia (Berl.) 55: 137-144

Dennison, W. C., Alberte, R. S. (1985). Role of daily light period in the depth distribution of Zostera marina (eelgrass). Mar. Ecol. Prog. Ser. 25: 51-61

Drew, E. A. (1978). Factors effecting photosynthesis and its seasonal variation in the seagrass Cymodocea nodosa 
(Ucria) Aschers., and Posidonia oceanica L. DeLile in the Mediterranean. J. exp. mar. Biol. Ecol. 31: 173-194

Drew, E. A. (1979). Physiological aspects of primary production in seagrasses. Aquat. Bot. 7: 139-150

Falkowski, P. (1980). Light-shade adaption in marine phytoplankton. In: Falkowski, P. (ed.) Primary production in the sea. Plenum Press, New York, p. 99-119

Fourqurean, J. W. (1987). Photosynthetic responses to temperature and salinity variation in three subtropical seagrasses. Master's thesis, Department of Environmental Sciences, University of Virginia

Gallegos, C. L., Platt, T. (1981). Photosynthesis measurement on natural populations of phytoplankton: numerical analysis. Can. Bull. Fish. Aquat. Sci. 210: 103-112

Giesen, W. B. J. T., van Katwijk, M. M., den Hartog, C. (1990). Eelgrass condition and turbidity in the Dutch Wadden Sea. Aquat. Bot. 37: 71-85

Jassby, A. D., Platt, T. (1976). Mathematical formulation of the relationship between photosynthesis and light for phytoplankton. Limnol. Oceanogr. 21: 540-547

Kelly, M. G., Moeslund, B., Thyssen, N. (1981). Productivity measurement and the storage of oxygen in the aerenchyma of aquatic macrophytes. Arch. Hydrobiol. 92 (1): 1-10

Kemp, W. M., Lewis, M. R., Jones, T. W. (1986). Comparison of methods for measuring production by the submersed macrophyte, Potomageton perfoliatus L. Limnol. Oceanogr. 31 (6): 1322-1334

Kenworthy, W. J., Fonseca, M. S. (1977). Reciprocal transplants of the seagrass Zostera marina L. effect of substrate on growth. Aquaculture 12: 197-213

Larkum, A. W. D., West, R. J. (1990). Long-term changes of seagrass meadows in Botany Bay, Australia. Aquat. Bot. 37: $55-70$

Lederman, T. C., Tett, P. (1981). Problems in modelling the photosynthesis-light relationship for phytoplankton. Botanica mar. 24: 125-134

Marsh, J. A., Dennison, W. C., Alberte, R. S. (1986). Effects of temperature on photosynthesis and respiration in eelgrass (Zostera marina L.). J. exp. mar. Biol. Ecol. 101: 257-267

Mazzella, L., Alberte, R. S. (1986). Light adaption and the role of autotrophic epiphytes in primary production of the temperate seagrass Zostera marina L. J. exp. mar. Biol. Ecol. 100: 165-180

Orth, R. J., Moore, K. J. (1983). Chesapeake Bay: an unprecedented decline in submerged aquatic vegetation. Science 222: 51-53

This article was presented by Dr G. W. Thayer, Beaufort, N. Carolina, USA
Rabinowitch, E., Govindjee (1969). Photosynthesis. Wiley, New York

Salisbury, F. B., Ross, C. W. (1978). Plant physiology, 2nd edn. Wadsworth Publishing Company, Belmont, California

Smith, E. L. (1936). Photosynthesis in relation to light and carbon dioxide. Proc. natn. Acad. Sci. 22: 504-511

Smith, R. D., Pregnall, A. M., Alberte, R. S. (1988). Effects of anaerobiosis on root metabolism of the seagrass Zostera marina L. (eelgrass). Mar. Biol. 98: 131-141

Steele, J. G. (1962). Environmental control of photosynthesis in the sea. Limnol. Oceanogr. 7: 137-150

Vicente, V. P., Rivera, J. A. (1982). Depth limits of the seagrass Thalassia testudinum (König) in Jobos and Guayanilla Bays, Puerto Rico. Carib. J. Sci. 17 (1-4): 73-77

Wahbeh, M. I. (1983). Productivity and respiration of three species of seagrasses from the Gulf of Aqaba (Jordan) and some related factors. Aquat. Bot. 367-374

Webb, W. L., Newton, M., Starr, D. (1974). Carbon dioxide exchange of Alnus rubra: a mathematical model. Oecologia (Berl.) 17: 281-291

Westlake, D. F. (1963). Comparisons of plant productivity. Biol. Rev. 38: 385-425

Westlake, D. F. (1978). Rapid exchange of oxygen between plant and water. Verh. int. Verein Limnol. 15: 426-436

Wetzel, R. L., Penhale, P. A. (1983). Transport of carbon and excretion of dissolved organic carbon by leaves and roots/ rhizomes in seagrasses and their epiphytes. Aquat. Bot. 6: $149-158$

Zieman, J. C. (1975). Tropical sea grass ecosystems and pollution. In: Wood, E. J. F., Johannes, R. E. (eds.) Tropical marine pollution. Elsevier oceanography series 12 . Elsevier Pub. Co., New York, p. 63-74

Zieman, J. C. (1982). The ecology of seagrasses of south Florida: a community profile. US Fish. Wildlife Serv. USFWS/OBS-82/25, Washington, D.C.

Zieman, J. C., Fourqurean, J. W., Iverson, R. L. (1989). The distribution, abundance and productivity of seagrasses in Florida Bay. Bull. mar. Sci. 44: 292-311

Zieman, J. C., Wetzel, R. G. (1980). Methods and rates of productivity in seagrasses. In: Phillips, R. C., McRoy, C. P. (eds.) Handbook of seagrass biology. Garland STMP Press, New York, p. 87-116

Zimmerman, R. C., Smith, R. D., Alberte, R. S. (1989). Thermal acclimation and whole-plant carbon balance in Zostera marina L. (eelgrass). J. exp. mar. Biol. Ecol. 130: 93-109

Manuscript first received: March 28, 1990

Revised version accepted: September 26, 1990 